\title{
Occurrence, Identification, and Pathogenicity of Fusarium spp. Associated with Tomato Wilt in Mexico
}

\author{
Micah R. ISAAC ${ }^{1}$, Santos G. LEYVA-MIR ${ }^{2}$, \\ Jaime SAHAGÚN-CASTELLANOS ${ }^{1}$, Kamila CÂMARA-CORREIA ${ }^{3}$, \\ Juan M. TOVAR-PEDRAZA², Juan E. RODRÍGUEZ-PÉREZ ${ }^{1 *}$
}

\author{
${ }^{1}$ Universidad Autónoma Chapingo, Departamento de Fitotecnia, Km. 38.5 Carretera México-Texcoco, CP 56230 Chapingo, Estado de México, \\ México;mickie50@hotmail.com; jsahagunc@yahoo.com.mx; erodriguezx@yahoo.com.mx(*correspondingauthor) \\ ${ }^{2}$ Universidad Autónoma Chapingo, Departamento de Parasitología Agricola, Km. 38.5 Carretera México-Texcoco, CP 56230 Chapingo, \\ Estado de México, México; lsantos@correo.chapingo.mx jmtovar@colpos.mx \\ ${ }^{3}$ Universidade Federal do Cariri, Centro de Ciências Agrárias e da Biodiversidade 63133-610 Crato, Ceará, Brazil; kamila.correia@ufca.edu.br
}

\begin{abstract}
Fusarium wilt is considered as one of the most important diseases that affects tomato (Solanum lycopersicum L.) cultivation. The objective of this study was to identify and characterize Fusarium species with the potential to cause tomato wilt using morphological and molecular approaches, in order to generate the necessary information to achieve effective control of this disease. Fusarium isolates were found associated with commercial grown cultivars with disease incidence ranging from 10 to $85 \%$. Forty isolates were identified by morphological characteristics as Fusarium oxysporum (38) and as Fusarium sp. (2). The isolates were evaluated for their pathogenicity on healthy tomato seedlings, which presented root rot at 20-35 days after inoculation. Fifteen of the most pathogenic isolates were analyzed with the internal transcribed spacer (ITS) region of DNA and the partial sequence of the translation elongation factor $1 \alpha(\mathrm{EF}-1 \alpha)$. Isolates associated with tomato wilt, were identified molecularly as Fusarium oxysporum (13), Fusarium circinatum (1), and Fusarium andiyazi (1). Both analysis revealed that the mayor agent of tomato wilt in Mexico was F. oxysporum. This finding provides relevant information on tomato wilt in Mexico to decide the proper control methods for the pathogen.
\end{abstract}

Keywords: characterization; Fusarium oxysporum complex; genotypes; ITS and EF-1 $\alpha$; phylogenetic tree; tomato

\section{Introduction}

Tomato (Solanum lycopersicum L.) is a high-value horticultural crop worldwide. The overall tomato production estimates 161 million ton and total production area of 8.5 million ha, in 2015. Mexico has shown remarkable development in tomato production and has been recognized as the second largest tomato exporter (FAOSTAT, 2015). However, tomato production has been tremendously limited by a high number of biotic and abiotic factors (Parke and Grünwald, 2012), among them, fungal soil-borne pathogens such as Fusarium oxysporum f. sp. radicis-lycopersici, first observed in 1969 in Japan (Sato and Araki, 1974), and Fusarium oxysporum f. sp. lycopersici, described over 100 years ago in the UK (Massee, 1895), causes tomato wilting (Inami et al., 2014), resulting in low yields and high economic losses (Arie et al., 2007; Panthee and Chen, 2010), exceeding $50 \%$ in production systems in Mexico (Apodaca et al., 2004).

Adequate identification of this pathogen is necessary to apply appropriate measures to reduce its negative effects (Takken and Rep, 2010). Morphological characteristics based on shape and size microconidia and macroconidia, phialides and the formation of chlamydospores (Rodrigues and Menezes, 2005), are the main form of identification and taxonomic description of Fusarium species (Leslie and Summerell, 2006). Additionally, modern molecular methods such as PCR and DNA sequence analysis of internal transcribed spacer (ITS) region and the translation elongation factor $1 \alpha(\mathrm{EF}-1 \alpha)$, are faster and more reliable to obtain proper identification (El-Kazzaz et al., 2008; Singha, 2016). 
Hence, the objectives of the present study were to determine the occurrence and incidence of Fusarium isolates in field and greenhouse conditions, in the central growing region of Mexico. Identify and characterize selected Fusarium isolates which causes tomato wilting, using morphological characteristics and sequence analysis of internal transcribed spacer (ITS) region of rDNA and the translation elongation factor $1 \alpha(\mathrm{EF}-1 \alpha)$, and to verify the pathogenicity in four commercial tomato varieties. Despite some studies which have addressed these problems (LeyvaMir et al., 2013), scarce information is available concerning occurrence, growth rates and phylogenetic relation of this pathogens found in fields and greenhouses production in Mexico. Thus, the finding in this study would provide relevant information on Fusarium species that affects tomato production in Mexico, to help decide the proper control methods to improve fruit yields.

\section{Materials and Methods}

\section{Sampling of plant tissue and isolation of fungi}

In 2014 and 2015, samples of tomato plants showing symptoms of wilting and chlorosis were obtained from a total of 12 different geographical locations in central Mexico, distributed in the states of Morelos, Puebla, and Tlaxcala (Fig. 1).

Symptomatic fragments were taken from the infected parts of the plant showing necrosis, dark brown and/or reddish coloration, sterilized in a 5\% sodium hypochlorite solution, rinsed with sterilized water and placed on potato dextrose agar (PDA) (Difco, USA) supplemented with $0.5 \mathrm{~g}$ $\mathrm{L}^{-1}$ of streptomycin sulphate (Sigma-Aldrich, USA) and 1 $\mathrm{ml} \mathrm{L}^{-1}$ of lactic acid. The Petri dishes were incubated at 26 ${ }^{\circ} \mathrm{C}$ for 3-5 days. Fungal colonies were transferred to fresh PDA medium and one colony per sample was re-isolated using a single spore (Leslie and Summerell, 2006). Forty of the isolates were stored in glycerol at $15 \%$ in cryogenic tubes at $-80^{\circ} \mathrm{C}$ for further investigations. The isolates used in this study were deposited in the Culture Collection of Phytopathogenic Fungi at the Universidad Autónoma Chapingo as UACH-202 to UACH-241. The disease incidence (\%) of stem and root infections was calculated as the ratio of total number of infected plants divided by the total number of examined plants, multiplied by 100.

\section{Morphological characterization}

For the morphological identification, pure cultures obtained from a single spore of each isolate were grown on PDA to examine the mycelium growth and appearance (Leslie and Summerell, 2006). To differentiate among isolates the presence or absence of chlamydospores, formation of sporodochia, width and length $(\mu \mathrm{m})$ of fifty random macroconidia and one hundred microconidia, were measured with the Motic Image Plus v. 4.0 (Motic Group", China). Isolates were grown on PDA and carnation leaf agar (CLA) medium. Wet chambers were used to observe the development of monophialides and/or polyphialides (Rodrigues and Menezes, 2005). Species of Fusarium were identified using the keys and descriptions reported by Booth (1971), Nelson et al. (1983), and Leslie and Summerell (2006). For characterization on culture medium, a 5-mm disc in diameter of each single spore isolate previously grown for 5-day-old on PDA medium, were placed at the center of each Petri dish and were incubated at $26 \pm 2{ }^{\circ} \mathrm{C}$ under darkness.

\section{Pathogenicity test}

The pathogenicity of 40 Fusarium isolates was verified on healthy 35-days-old tomato seedlings of four commercial tomato cultivars ('Rio Grande', 'Moctezuma $\mathrm{F}_{1}$ ', 'Floradade', and 'DRW $7744 \quad F_{1}$ ') under greenhouse conditions. Conidial suspension of each fungal isolate was prepared using sterile distilled water and conidia of 7-daysold colonies to inoculate each plant. The concentration of the conidial suspension was adjusted to $10^{6}$ spores $\mathrm{mL}^{-1}$ including macroconidia and microconidia, using a hemocytometer. The inoculated plants were transplanted in styrofoam cups (1L) as described by Shahnazi et al. (2012). Data collection were carried out at 5, 10, 15, 20, 25, 30, and 35 days after inoculation (DAI). To determine the severity a visual scale was designed based on the percentage of affected plants, where $1=$ no symptoms; $2=$ initial symptoms or 10 $20 \%$ chlorosis of leaves; $3=20-50 \%$ chlorosis of leaves; $4=$ $>50 \%$ chlorosis of leaves and initial symptoms flaccidity of the top leaves; $5=$ completely or the major part of the plant wilted or death.

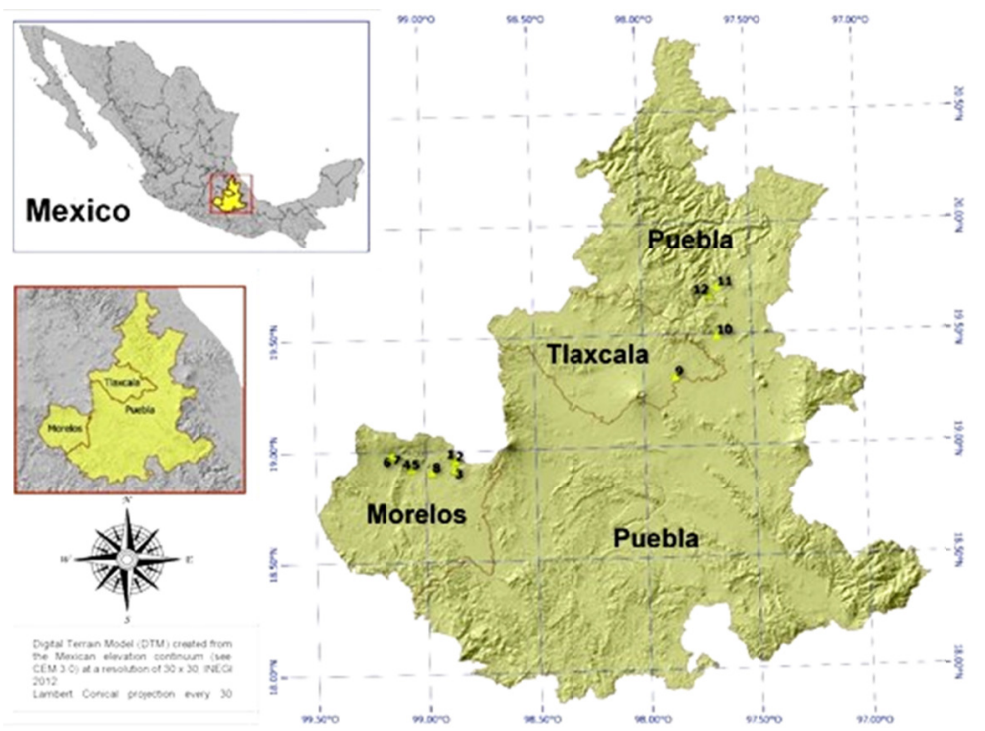

Fig. 1. Tomato growing areas sampled in central Mexico (Morelos, Puebla and Tlaxcala), in the growing season of 2014 and 2015 
486

Dry weight of the plants following oven drying at $80^{\circ} \mathrm{C}$ for $48 \mathrm{~h}$, along with internal lesion was registered. The experimental design of pathogenicity test was a completely randomized block with four replicates. The experimental unit was five styrofoam cups. Area under the disease progress curve (AUDPC) was calculated according to Campbell and Madden (1990). The AUDPC values were used to classify the level of pathogenicity among the different Fusarium species. Analysis of variance (ANOVA) of the data was performed with the SAS v. 9.3 (2012). The mean values of the treatments were compared using the Tukey test $(\mathrm{p} \leq 0.05)$.

\section{Radial growth rate}

The radial growth $(\mathrm{cm})$ of the fungal isolates was recorded in $24 \mathrm{~h}$ intervals during seven days. The experiment was performed twice, each one with three replicates. The radial growth of the isolates was estimated with the respective slopes of the simple linear regressions, obtained using the time (days) as independent variable and radial growth as the dependent variable (Lamrani, 2009). The radial growth was classified as: fast $\left(\beta_{1}>12\right)$, moderate $\left(7 \leq \beta_{1} \leq 12\right)$ and slow growth $\left(\beta_{1}<7\right)$. The final radial growth measurement and area under disease progress curve (AUDPC), were calculated and submitted to an analysis of variance procedure. The mean values of the isolates were compared with the Tukey test $(P \leq 0.05)$.

\section{DNA extraction, PCR amplification and sequencing}

DNA extraction was performed only for 15 isolates with seven-day-old mycelial colony growth on PDA medium in Petri dishes at $26^{\circ} \mathrm{C}$. Mycelium and conidia of each isolate was scrapped and ground to a fine powder under liquid nitrogen using a mortar and pestle. DNA extraction was done by using The DNeasy Plant Mini Kit (Qiagen', USA) according to the manufacturer's instructions. DNA was visualized on $1 \%$ agarose gels, with TAE $1 \mathrm{X}$ buffer and 5 $\mu \mathrm{L}$ of the PCR product at 90 Volts. The gel was analysed in a Transilluminator Gel Doc-It TM 300 (UVP', UK) and stored at $-20{ }^{\circ} \mathrm{C}$. For Fusarium species identification, the internal transcribed spacer (ITS) region of DNA was amplified using the primers ITS5/ ITS4 (White et al., 1990), and the partial sequence of the translation elongation factor $1 \alpha(\mathrm{EF}-1 \alpha)$ gene using the primers EF1728F/EF1-986R (O'Donnell et al., 1998). PCR products were prepared to a final volume of $50 \mu \mathrm{L}$, containing PCR buffer (1x), $2.5 \mu \mathrm{L} \mathrm{MgCl}_{2}, 0.2 \mathrm{mM}$ of $1 \mu \mathrm{L}$ dNTP, $0.8 \mu \mathrm{L}$ of each primer, $1 \mathrm{U}$ of DNA polymerase (Promega ${ }^{\circ}, \mathrm{USA}$ ) and $100 \mathrm{ng}$ of DNA and was carried out in a C-1000TM Thermal Cycler (Biorad, USA). The amplified products were sent to MACROGEN (Korea) for sequencing.

\section{Phylogenetic analysis}

The phylogeny was reconstructed by analyses from sequences of the ITS region and EF- $1 \alpha$ gene. Forward and reverse sequences were assembled using the Staden Package (Staden et al., 1998). Sequences generated in this study were supplemented with additional sequences obtained from GenBank, based on BLASTn searches and the literature. Sequences of the isolates were aligned using ClustalX v. 1.81 (Thompson et al., 1997) and manual adjusted. Individual alignments of ITS and EF- $1 \alpha$ dataset were analysed with Maximum Likelihood and Maximum Parsimony using MEGA5 (Tamura et al., 2011) with partial deletion of gaps, substitution models proposed by this program and 1000 bootstrap replicates. The obtained sequences were deposited in the NCBI database (GenBank accession numbers: ITS, MG557855-MG557869; EF-1 a MG557870-MG557884).

\section{Results and Discussion}

\section{Field and greenhouse sampling}

Fusarium wilting was observed in the 120 samples (Fig. 1) obtained from tomato plants (two to five months old) of twelve locations in three states of Mexico (Fig. 2a-b) in field and greenhouse conditions; typical symptoms were more prominent in the field. The disease incidence varied from 10-85\%; the highest was observed in Apanquetzalco, Morelos (82\%), grown in the field. Meanwhile, the lowest was observed in a greenhouse located in Tlaxcala, with $12 \%$. 'Pony Express' was the most affected cultivar followed by 'Tisey-DRD8551', 'Serengheti', and 'Reserva', with intermediate incidence; while 'Cid' and 'Moctezuma' were less affected (Table 1). Those results were similar to those reported by Hernández-Martinez et al. (2014), indicating that Tomato wilt is one of the most devastating disease, resulting in 40-70\% in economic losses around the world.

The severity and incidence of this pathogen is conditioned according to the geographical location, climatic factors, cultural practices (Daami-Remadi, 2006), and physiology of the host plant (Tivoli et al., 1986). According to Nirmaladevi et al. (2016) Tomato wilt occurs in most cultivated soils and is isolated mainly from contaminated plants tissues. Many of these plants grown in these soils may become infected to some degree during their life cycle, suggesting their potential involvement in the spread and incidence of the disease (Rajput et al., 2008). Our results confirms that observation. The effect of Tomato wilt is most apparent during the flowering stage when the plant and its productivity are more sensitive to stress (GargouriKammoun et al., 2009; Panthee and Chen, 2010; Siddique et al., 2014).

The fields where tomato plants were cultivated are often subjected to crop rotation of other Gramineae (millet, corn, sorghum, rice and sugarcane), and Solanaceous crops (potato, pepper, and eggplant), suggesting the source of transmission of Fusarium spp. (Trabelsi et al., 2017). Thus, these crops can increase the pathogen population in the soil in a very efficient way (Cai et al., 2011). However, wilting caused by Fusarium spp. in Mexico has not been fully documented, despite its significant impact on commercial production and yields of tomato plants. This could be explained because Mexico is the centre of domestication for tomato, indicating the widespread variability of different tomato cultivars (Marin-Montes et al., 2016), therefore, increasing the distribution, variability and evolution of Fusarium spp. (Inami et al., 2014).

\section{Morphological characteristics and growth rate of the Fusarium species}

The Fusarium isolates exhibited colonies on PDA 

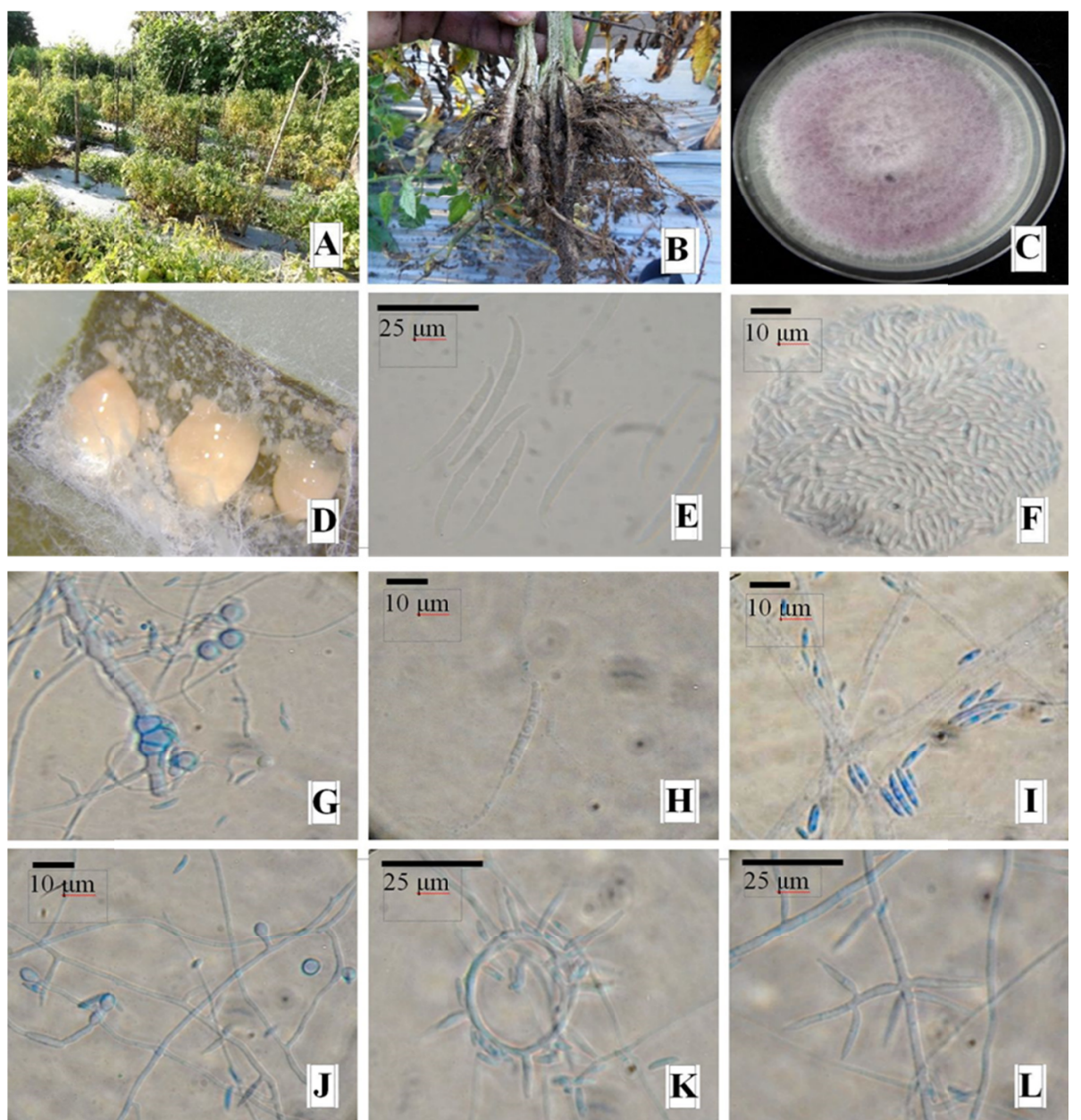

Fig. 2. Symptoms, colony, and morphological characteristics of Fusarium spp. (A). Yellowing symptioms of tomato plants in open field conditions. (B). Dark lesions and discoloration of tomato stems. (C). Violet colour of Fusarium oxysporum colony grown in PDA medium. (D). Mass of sporodochia F. oxysporum (E). Macroconidia of F. oxysporum. (F). Mass of microconidia of $F$. oxysporum. (G). Pseudochlamydospores of Fusarium andiyazi. (H). Macroconidia of $F$. andiyazi. (I). Microconidia of $F$. andiyazi. (J). Chlamydospores of $F$. oxysporum. (K). Coiled hyphae of Fusarium circinatum. (L). Monophialides of F. circinatum

Table 1. Mean incidence of tomato (Solanum lycopersicum L.) wilting in different field and greenhouse systems in Central Mexico

\begin{tabular}{|c|c|c|c|c|c|c|c|c|}
\hline State & $\begin{array}{c}\text { Place of sample } \\
\text { collection }\end{array}$ & GPS Coordinates & $\begin{array}{l}\text { Altitude } \\
(\mathrm{msl})\end{array}$ & $\begin{array}{l}\text { Production } \\
\text { System type }\end{array}$ & $\begin{array}{l}\text { Plant age } \\
\text { (months) }\end{array}$ & Tomato cultivar & $\begin{array}{c}\text { Tornato growth } \\
\text { type }\end{array}$ & $\%$ Mean incidence \\
\hline Morelos & Atlatlahucan & $\begin{array}{l}20.971^{\circ} \mathrm{N} \\
51.372^{\circ} \mathrm{E}\end{array}$ & 1817 & Field & 2.5 & 'Serengheti' & Dieterminate & 27 \\
\hline Morelos & Atlatlahucan & $\begin{array}{l}20.959^{\circ} \mathrm{N} \\
51.419^{\circ} \mathrm{E}\end{array}$ & 1785 & Field & 2 & 'Pony Express' & Dieterminate & 22 \\
\hline Morelos & Yecapixtla & $\begin{array}{l}20.917^{\circ} \mathrm{N} \\
51.388^{\circ} \mathrm{E}\end{array}$ & 1774 & Field & 3.5 & 'Tisey-DRD 8551' & Dieterminate & 20.83 \\
\hline Morelos & Almincingo & $\begin{array}{l}20.922^{\circ} \mathrm{N} \\
49.281^{\circ} \mathrm{E}\end{array}$ & 1254 & Field & 4 & 'Rio Grande' & Determinate & 46.67 \\
\hline Morelos & Apanquetzalco & $\begin{array}{l}20.923^{\circ} \mathrm{N} \\
49.325^{\circ} \mathrm{E}\end{array}$ & 1250 & Field & 3 & 'Pony Express' & Dieterminate & 82 \\
\hline Morelos & Santa Catarina & $\begin{array}{l}20.981^{\circ} \mathrm{N} \\
48.245^{\circ} \mathrm{E}\end{array}$ & 1676 & Field & 3 & 'Tisey-DRD 8551' & Determinate & 26 \\
\hline Morelos & Santa Catarina & $\begin{array}{l}20.993^{\circ} \mathrm{N} \\
48.451^{\circ} \mathrm{E}\end{array}$ & 1746 & Field & 3 & 'Pony Express' & Dieterminate & 29.1 \\
\hline Morelos & Oaxtepec & $\begin{array}{l}20.904^{\circ} \mathrm{N} \\
50.312^{\circ} \mathrm{E}\end{array}$ & 1250 & Field & 3 & 'Pony Express' & Dieterminate & 39.44 \\
\hline Tlaxcala & Huamantla & $\begin{array}{l}21.360^{\circ} \mathrm{N} \\
62.026^{\circ} \mathrm{E}\end{array}$ & 2422 & Greenhouse & 4 & 'Cid' & Indeterminate & 12 \\
\hline Puebla & Libres & $\begin{array}{l}21.562^{\circ} \mathrm{N} \\
64.044^{\circ} \mathrm{E}\end{array}$ & 2376 & Greenhouse & 5 & 'Moctezuma' & Indeterminate & 27 \\
\hline Puebla & San Miguel & $\begin{array}{l}21.802^{\circ} \mathrm{N} \\
64.107^{\circ} \mathrm{E}\end{array}$ & 2107 & Greenhouse & 4 & 'Cid' & Indeterminate & 18 \\
\hline Puebla & Zautla & $\begin{array}{l}21.761^{\circ} \mathrm{N} \\
63.703^{\circ} \mathrm{E}\end{array}$ & 2037 & Greenhouse & 4 & 'Reserva' & Indeterminate & 29 \\
\hline
\end{tabular}


488

medium that were red, white, purple, brown and pink in color. The colonies showed diversity according to the morphological characteristics based on macroconidia, microconidia, clamydospores and phialides (Fig. 2 e-l), described by Nelson et al. (1983) and Leslie and Summerell (2006). Thirty-eight isolates were classified as Fusarium oxysporum and two as Fusarium sp. (Isolates 1 and 2) which varied in shape and size and were similar to those defined by Zainudin et al. (2010).

Mycelia of Fusarium oxysporum isolates were sparse to abundant, while the colours ranged from white to pink, and often pale violet. Macroconidia presented were also sparse to abundant, are formed from monophialides on branched conidiophores or on the surface of sporodochia (Fig. 2d), ranging from orange to brown. Three-septate macroconidia were most common although four thin walled septate were also presented. The macroconidia measured 26.5 to $36.1 \times 2.6$ to $4.6 \mu \mathrm{m}$. The microconidia presented 0 -septate, oval, elliptical or reniform (kidney-shaped), and were formed abundantly in false heads on short monophialides. The microconidia measured 3.4 to $12 \times 2$ to $3.3 \mu \mathrm{m}$. Chlamydospores were formed abundantly in hyphae, singly or in pairs, terminally or on an intercalary basis presenting both smooth and rough walls. In carnation leaf agar (CLA) medium some of the isolates presented chlamydospores after 21 days. The Fusarium oxysporum isolates exhibited a high level of diversity presenting a wide range of colours and morphological structures. All 38 isolates were consistent with reports by Leslie and Summerell (2006). This species is considered as the principal causal agent of tomato wilt and Fusarium crown rot (Tanyolac and Akkale, 2010) in vegetable plants.

The isolate classified as Fusarium sp. (Isolate 1), exhibited abundant aerial mycelium, the color of the colony was initially white then turned to red and violet. The macroconidia were straight or slightly curved, with 3-4 septate, 38.6 to $46 \times 2.7$ to $3.4 \mu \mathrm{m}$ (Fig. $2 \mathrm{~h}$ ). Sporodochia were rarely observed on CLA medium. The microconidia were oval, with a flat base, without septa, of 9.2 to $10.9 \times 2.6$ to $2.8 \mu \mathrm{m}$, formed in monophialide in conidiophores sometimes branched, in false heads or long chains of more than 12 conidia. After 3-4 weeks in PDA medium, pseudochlamydospores in hyphae with smooth walls, and in short chains were observed (Fig. 2g). These observations were similar to those of Fusarium andiyazi which have been associated with sorghum, in Africa and USA (Marasas et al., 2001), with rice bakanae, in Asia and Africa (Wulff et al., 2010), and with corn in Siria (Madamia et al., 2013). Fusarium andiyazi is a major pathogen of sorghum (Klittich et al., 1997; Marasas et al., 2001) and can be distinguished from other Fusarium spp., mainly Fusarium verticillioides, Fusarium thapsinum, and Fusarium musae, based on its production of pseudochlamydospores in PDA medium (Van Hove et al., 2011). These structures are distinguishable from true chlamydospores because they have no surface ornamentation and they are not thick- or double-walled (Leslie and Summerell 2006). According to Klaasen and Nelson (1998), pseudochlamydospores differ from 'swollen hyphal cells' because they do not have transverse septa (Marasas et al., 2001).

On the other hand, the isolate classified as Fusarium sp. (Isolate 2) presented aerial mycelium was white, or slightly violet. The colony exhibited growth rate relatively rapidly. In CLA, coiled hyphae (Fig. $2 \mathrm{k}$ ) were observed, but these characters are shared with species like $F$. mexicanum, $F$. pseudocircinatum, F. sterilihyphosum, and $F$. tupiense (Nirenberg and O'Donnell, 1998; Britz et al., 2002; Lima et al., 2012). Macroconidia were typically 3 -septate, with slightly curved walls, measuring 32 to $42 \times 3.3$ to $3.8 \mu \mathrm{m}$. Microconidia were typically single-celled, ovoid (or nearly oval), were borne in false heads on aerial polyphialides. The microconidia measured 7.6 to $11.8 \times 1.8$ to $3.5 \mu \mathrm{m}$. Presented proliferation of microconidiophores, coupled with a slight twisting of the aerial mycelium on which they are borne, differentiating the morphology of the colony. Chlamydospores were absent. These observations were similar to those of Fusarium circinatum (Leslie and Summerell 2006), which was recently reported in association with grass species as symptomless hosts in the proximity of Pinus stands (Sweet and Gordon, 2012) in which it has the ability to survive in alternative hosts which is relevant for establishment and subsequent dissemination of the pathogen to new areas. The fungus is also associated with significant losses in yield and productivity, making it one of the most important limitations to commercial forestry (Wingfield et al., 2008; Mitchell et al., 2011). According to Steenkamp et al. (2014), it is widely believed that Central America and Mexico represents the centre of origin of $F$. circinatum this based on the high levels of

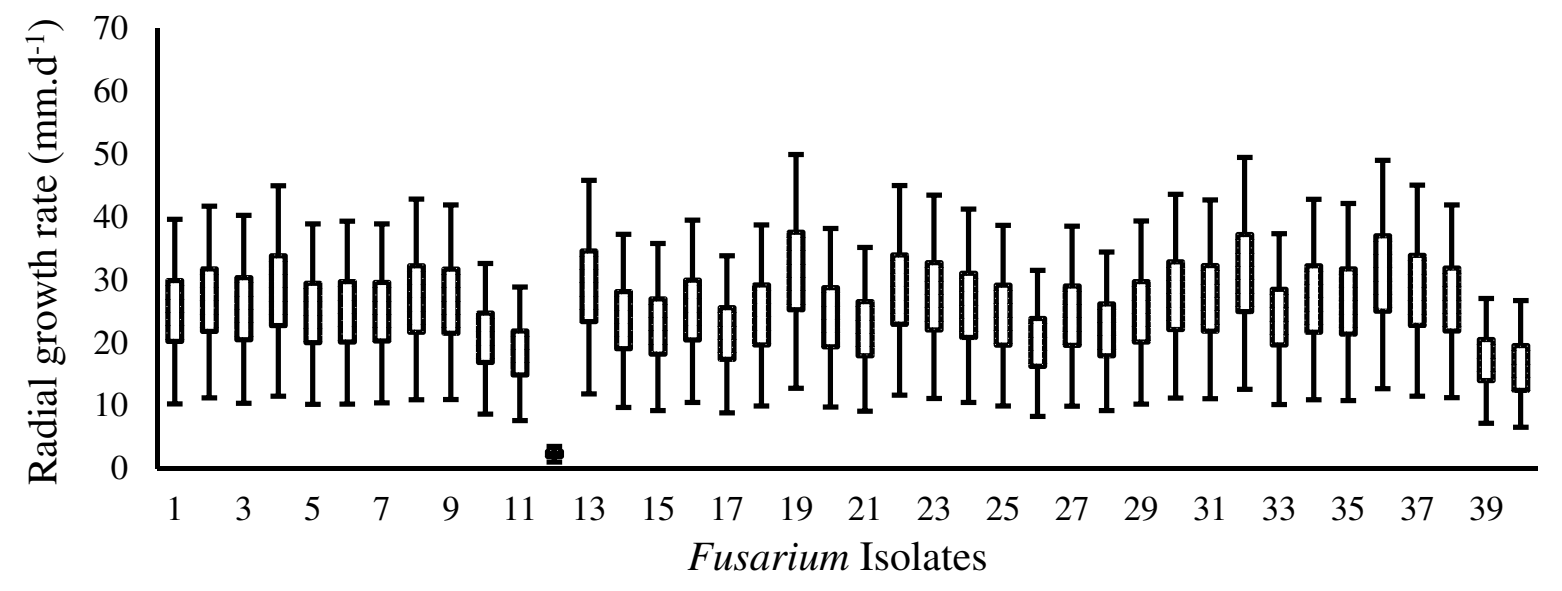

Fig. 3. Radial growth rate values $\left(\beta_{1,} \mathrm{~cm}^{-1}\right)$ of 40 Fusarium isolates (lines represent the $95 \%$ confidence intervals) 
genetic diversity among species and the wide number of Pinus trees produced in Mexico, generating coevolution of both (Britz et al., 2005).

The radial growth $\left(\beta_{1}, \mathrm{~mm} \mathrm{~d}^{-1}\right)$ for the 40 Fusarium isolates, obtained by linear regression in a period of five to seven days in PDA medium (Fig. 3), showed $\mathrm{R}^{2}$ 's above 0.8 and all the $\beta_{1}$ values were different to zero $(P<0.01)$. Three isolates (UACH-216, UACH-234, and UACH-238) showed fast growth $\left(12.0-12.3 \mathrm{~mm} \mathrm{~d}^{-1}\right)$ which reached maximum growth on the 5th day of incubation; while 34 isolates exhibited moderate growth $\left(7.6-11.2 \mathrm{~mm} \mathrm{~d}^{-1}\right)$, and three (UACH-213, UACH-241, and UACH-212) presented slow growth $\left(0.8-6.9 \mathrm{~mm} \mathrm{~d}^{-1}\right)$. The isolates with maximum growth covered the Petri dish by a $100 \%$ on the 7th day; while the isolates with minimal growth only covered by $50 \%$. Chehri et al. (2015) mentioned that the growth rate of Fusarium solani were $5.5-8.6 \mathrm{~mm} \mathrm{~d}^{-1}$, this were slightly under the results obtained in the study 6.9-12 $\mathrm{mm} \mathrm{d} \mathrm{d}^{-1}$ (Fig. 3), this probably due to difference in temperature and light intensity used during the experiment. According to Brock et al. (1994) and Trabelsi et al. (2017), fungal growth under natural conditions is very slow due to the low intake of substrates and to the variation of nutrient distribution among microbial habitats. Growth also depends on other factors such the antagonistic interactions (Giurgiu et al., 2017) with other species like Trichoderma spp. competing for the space and nutrients (Marzano et al., 2013), drought and moisture conditions, stress caused by nutrient depletion, and changes in temperature and soil $\mathrm{pH}$ (Trabelsi et al., 2017). This helps to explain the capacity of the Fusarium species in adapting and growing under a different and wide range of environmental conditions.

\section{Pathogenicity test and the response of the tomato cultivars}

The pathogenicity test showed considerably differences among isolates in terms of their ability to cause disease as mentioned by Joshi $e t$ al. (2013). In this study, 15 isolates were highly pathogenic, 15 showed moderate pathogenicity, and 10 were weak. Symptoms were presented 21-35 days after inoculation in which the leaves presented yellowing flaccidity and wilting. Necrosis and a brownish discoloration were also observed on roots and stem as well as a reddish coloration of vascular tissues as shown in Fig. 2. Furthermore, the inoculated fungi were re-isolated from plants that showed witling symptoms, while no symptoms were found on control plants, for this reason the Koch's postulates were confirmed. ANOVA results of disease severity of Fusarium spp. were variable where AUDPC, internal lesion, dry weight, and fresh weight values indicated highly significant differences among the inoculated isolates and cultivars (Table 2$)$ as well as for their interaction $(P \leq$ $0.01)$. The means comparison for cultivars indicated that 'Moctezuma' showed higher resistance to Fusarium by presenting the lowest AUDPC, and higher fresh and dry weight (Table 2); although the internal lesion was high. In contrast, 'Rio Grande', 'Floradade', and '7744' presented similar performance showing high susceptibility. According to Steinkellner et al. (2005) the pathogenicity of Fusarium in tomato could be affected by the Fusarium race, internal factor such as enzymes, growth-regulating compounds, toxins, gummosis; and environmental and growing conditions among them nutrition, phenological stage, and cultural management. Jiménez-Fernández et al. (2010) mentioned $F$. oxysporum are responsible for wilt diseases on many plants of economic importance other than tomato. Pathogenic strains show high levels of host specificity and are classified on this basis into formae speciales and races. Ajit et al. (2006) also reported that $F$. oxysporum has approximately 80 formae speciales divided into pathotypes specific to species, and subdivided into races specific to cultivar within a species.

\section{Molecular characterization}

Molecular characterization based on analyses of ITS and EF-1 $1 \alpha$ sequences confirmed the findings of the morphological observations, hence the importance of combining both morphological and genetic data for fungal identification (Correia et al., 2013). Fusarium isolates associated with tomato wilt formed three genetic clusters based on (EF-1 $\alpha)$ analysis (Fig. 4). The phylogenetic tree resulting in the formation of three major clusters. According to Aoki et al. (2014), primers used in any study must be specific for the correct amplification of Fusarium spp. This situation proves that the majority of the Fusarium isolates pertains to the Fusarium oxysporum complex, one as Fusarium andiyazi, and one as Fusarium circinatum. The last two isolates forms part of the Gibberella fujikuroi complex (Fig. 3). Several studies have shown that phylogenetic species criterion is most appropriate and congruent (O'Donnell et al., 1998; Cai et al., 2011; Bashyal and Aggarwal, 2013).

For example, phylogenetic analyses have revealed the existence of several cryptic species (Steenkamp et al., 2002) such as Fusarium subglutinans, using the genes translation elongation factor $1 \alpha$ gene $(\mathrm{EF}-1 \alpha)$ and the DNA sequences of ITS regions for specie recognition, thus, offering a finer resolution, separating strains of most Fusarium complex species (Hsuan et al., 2011; Irzykowska et al., 2012). The identification of the genera Fusarium on a species level is essential because species are used as the basic units of analysis

Table 2. Means comparisons of four varieties of tomatoes during pathogenicity test

\begin{tabular}{ccccccccc}
\hline Variety & $\begin{array}{c}\text { Severity } \\
\text { (AUDPC) }\end{array}$ & & Internal lesion $(\mathrm{cm})$ & \multicolumn{1}{c}{$\begin{array}{c}\text { Dry } \\
\text { weight }(\mathrm{g})\end{array}$} & & Fresh weight $(\mathrm{g})$ \\
\hline 'Rio Grande' & 948.05 & $\mathrm{a}$ & 32.112 & $\mathrm{~b}$ & 1.627 & $\mathrm{c}$ & 86.219 & $\mathrm{c}$ \\
\hline 'Moctezuma' & 439.02 & $\mathrm{~d}$ & 39.005 & $\mathrm{a}$ & 4.2751 & $\mathrm{a}$ & 210.098 & $\mathrm{a}$ \\
\hline 'Floradade' & 833.66 & $\mathrm{~b}$ & 32.372 & $\mathrm{~b}$ & 1.4255 & $\mathrm{c}$ & 83.96 & $\mathrm{c}$ \\
\hline '7744' & 712.93 & $\mathrm{c}$ & 33.501 & $\mathrm{~b}$ & 2.6434 & $\mathrm{~b}$ & 138.935 & $\mathrm{~b}$ \\
HSD & 15.892 & & 3.2628 & & 0.2901 & & 15.053 \\
\hline Note: HSD: Honest significant difference & & & & & & & &
\end{tabular}

Different letters in each column indicates significant difference (Tukey, $P<0.05$ ). 


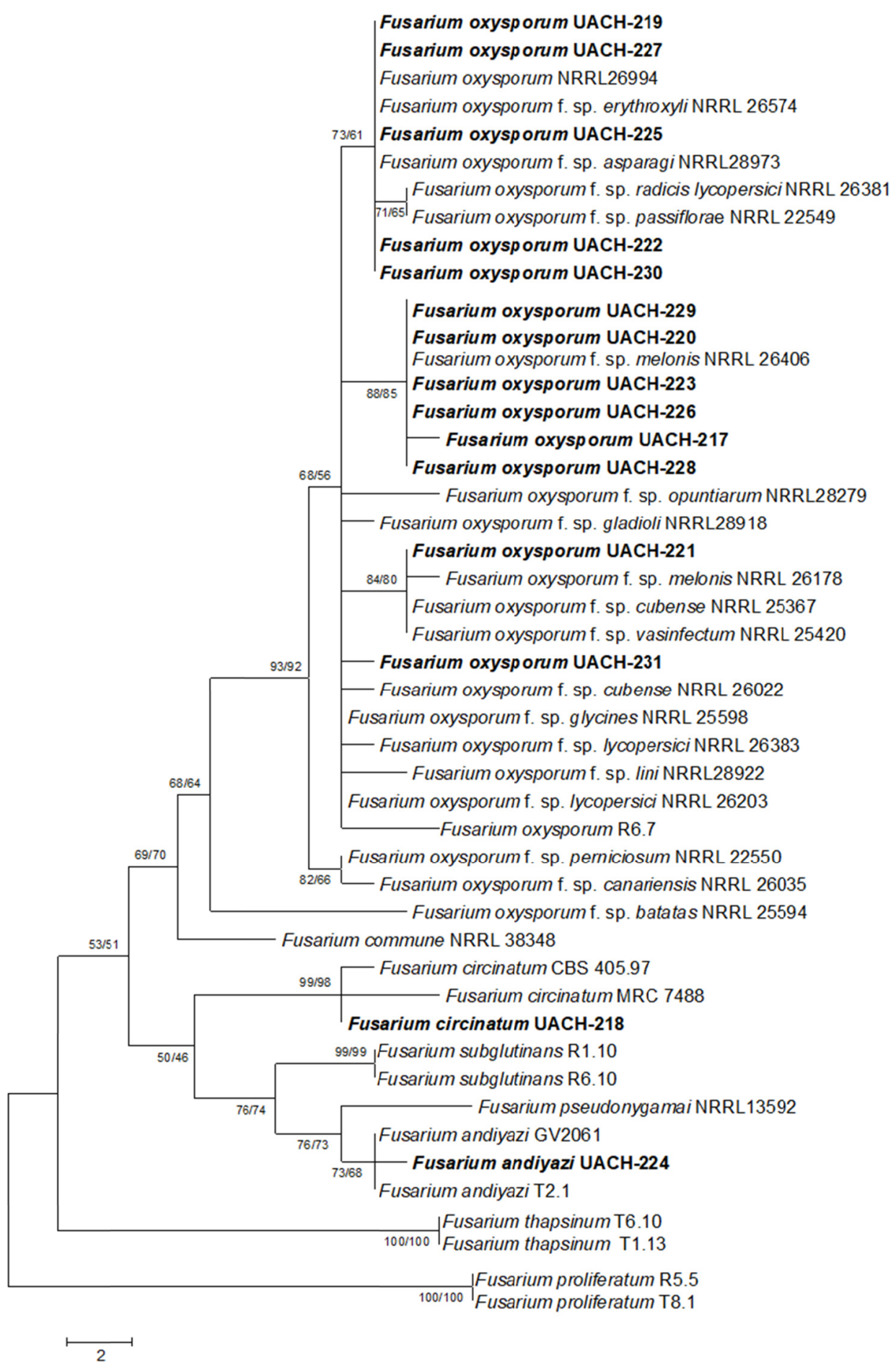

Fig. 4. Maximum parsimony tree generated from sequence analysis of the EF-1 $\alpha$ gene dataset. Designated outgroup taxa are Fusarium thapsinum and F. proliferatum. Bootstrap support values for maximum parsimony (left) and maximum likelihood (right) are indicated at the nodes. The isolates in this study are in boldface

Table 3. Results of pathogenicity test of Fusarium spp. Isolates

\begin{tabular}{|c|c|c|c|c|c|c|c|c|c|c|}
\hline \multirow{2}{*}{$\begin{array}{c}\text { County } \\
\text { Atlatlahucan }\end{array}$} & \multirow{2}{*}{$\begin{array}{c}\text { Code } \\
\text { UACH-202 }\end{array}$} & \multicolumn{2}{|c|}{$\begin{array}{c}\text { Severity } \\
\text { (AUDPC) }\end{array}$} & \multirow{2}{*}{$\begin{array}{l}\text { Severity } \\
\text { Weak }\end{array}$} & \multicolumn{2}{|c|}{ Internal lesion $(\mathrm{cm})$} & \multicolumn{2}{|c|}{ Dry weight (g) } & \multicolumn{2}{|c|}{ Fresh weight ( $\mathrm{g}$} \\
\hline & & 400 & op & & 38.8 & $c-k$ & 1.7 & h-k & 85 & $\mathrm{ijk}$ \\
\hline $\begin{array}{c}\text { Santa Catarina } \\
\text { Monte }\end{array}$ & UACH-203 & 985 & $d-f$ & High & 12.4 & op & 1.4 & k & 68.5 & $\mathrm{jk}$ \\
\hline Apanquetzalco & UACH-204 & 415 & op & Weak & 24.4 & $k-p$ & 1.7 & $h-k$ & 87 & $h-k$ \\
\hline Atlatlahucan & UACH-205 & 760 & $f-i$ & High & 17.6 & nop & 1.7 & h-k & 86 & h-k \\
\hline
\end{tabular}




\begin{tabular}{|c|c|c|c|c|c|c|c|c|c|c|}
\hline Atlatlahucan & UACH-206 & 880 & efg & High & 25.6 & j-o & 1.7 & h-k & 95 & $e-k$ \\
\hline San Miguel & UACH-207 & 428 & op & Weak & 41.1 & $b-i$ & 1.8 & $g-k$ & 85 & $\mathrm{ijk}$ \\
\hline Libres & UACH-208 & 548 & $i-n$ & Moderate & 48 & b-e & 2.8 & $c-j$ & 138 & $b-j$ \\
\hline San Miguel & UACH-209 & 350 & $\mathrm{p}$ & Weak & 51.8 & $a-d$ & 3.4 & b-e & 190 & $\mathrm{~b}$ \\
\hline Zuautla & UACH-210 & 843 & $e-h$ & High & 25.1 & k-o & 1.7 & h-k & 90.5 & $\mathrm{f}-\mathrm{k}$ \\
\hline Santa Catarina & UACH-211 & 765 & $\mathrm{f}-\mathrm{g}$ & High & 46.2 & $\mathrm{c}-\mathrm{g}$ & 3.5 & b-e & 190 & $\mathrm{~b}$ \\
\hline Oaxtepec & UACH-212 & 828 & $e-h$ & High & 36.4 & $\mathrm{~d}-1$ & 1.5 & $\mathrm{jk}$ & 81 & ijk \\
\hline Apanquetzalco & UACH-213 & 465 & $k-p$ & Moderate & 45.1 & b-g & 4.5 & $\mathrm{ab}$ & 185 & $\mathrm{~b}$ \\
\hline San Miguel & UACH-214 & 783 & $\mathrm{f}-\mathrm{h}$ & High & 22.1 & $1-p$ & 2.3 & $e-k$ & 133 & b-k \\
\hline San Miguel & UACH-215 & 1395 & $a b$ & High & 12.4 & op & 1.4 & $\mathrm{jk}$ & 76 & $\mathrm{ijk}$ \\
\hline Yecapixtla & UACH-216 & 435 & $n-p$ & Weak & 26.4 & 1-o & 1.6 & h-k & 102 & $c-k$ \\
\hline Huamantla & UACH-217 & 605 & $g-p$ & Moderate & 52.3 & $a b c$ & 3 & $\mathrm{c}-\mathrm{h}$ & 163 & $b-f$ \\
\hline Atlatlahucan & UACH-218 & 478 & $\mathrm{j}-1$ & Moderate & 67.1 & $\mathrm{a}$ & 3.2 & $b-f$ & 172.9 & bc \\
\hline Almincingo & UACH-219 & 470 & $1-p$ & Moderate & 36.7 & $\mathrm{c}-1$ & 3.5 & $b-d$ & 200 & $\mathrm{~b}$ \\
\hline Huamantla & UACH-220 & 1698 & a & High & 50.3 & $\mathrm{cbd}$ & 3.7 & bed & 200 & $\mathrm{~b}$ \\
\hline Huamantla & UACH-221 & 640 & h-o & Moderate & 31.7 & $\mathrm{f}-1$ & 3.1 & b-g & 162 & b-g \\
\hline Almincingo & UACH-222 & 590 & $i-p$ & Moderate & 46.6 & $b-f$ & 3 & $\mathrm{c}-\mathrm{h}$ & 170 & bcd \\
\hline Santa Catarina & UACH-223 & 710 & $\mathrm{f}-\mathrm{l}$ & Moderate & 24.4 & $\mathrm{k}-\mathrm{p}$ & 1.8 & $\mathrm{f}-\mathrm{k}$ & 107 & $\mathrm{c}-\mathrm{k}$ \\
\hline Huamantla & UACH-224 & 1218 & bcd & High & 29.2 & h-l & 1.8 & $\mathrm{f}-\mathrm{k}$ & 97.8 & $\mathrm{f}-\mathrm{k}$ \\
\hline Apanquetzalco & UACH-225 & 743 & $\mathrm{f}-\mathrm{l}$ & Moderate & 27.8 & i-l & 2.4 & $\mathrm{~d}-\mathrm{k}$ & 129 & $\mathrm{~b}-\mathrm{k}$ \\
\hline Apanquetzalco & UACH-226 & 663 & $\mathrm{j}-1$ & Moderate & 29.7 & $i-n$ & 3.4 & b-e & 161 & b-g \\
\hline Apanquetzalco & UACH-227 & 1073 & $c-d$ & High & 29.8 & $i-n$ & 1.4 & $\mathrm{kj}$ & 79 & $\mathrm{ijk}$ \\
\hline Apanquetzalco & UACH-228 & 730 & $\mathrm{f}-\mathrm{l}$ & Moderate & 26.6 & $j-o$ & 2.5 & $\mathrm{c}-\mathrm{k}$ & 147 & $b-i$ \\
\hline Apanquetzalco & UACH-229 & 973 & def & High & 24.7 & $\mathrm{k}-\mathrm{p}$ & 1.6 & ijk & 103.3 & $\mathrm{c}-\mathrm{k}$ \\
\hline Libres & UACH-230 & 715 & $\mathrm{f}-\mathrm{l}$ & Moderate & 34.3 & $e-m$ & 1.8 & $\mathrm{~g}-\mathrm{k}$ & 83.6 & $\mathrm{ijk}$ \\
\hline Libres & UACH-231 & 1268 & $\mathrm{bc}$ & High & 33.9 & $\mathrm{f}-1$ & 1.9 & $\mathrm{f}-\mathrm{k}$ & 99 & $\mathrm{~d}-\mathrm{k}$ \\
\hline Apanquetzalco & UACH-232 & 650 & h-l & Moderate & 30.5 & $\mathrm{i}-\mathrm{m}$ & 2.1 & $e-k$ & 133 & $\mathrm{~b}-\mathrm{k}$ \\
\hline Apanquetzalco & UACH-233 & 753 & $f-j$ & Moderate & 25 & k-o & 1.7 & $\mathrm{~h}-\mathrm{k}$ & 106 & $\mathrm{c}-\mathrm{k}$ \\
\hline Huamantla & UACH-234 & 1430 & $a b$ & High & 51.4 & $a-d$ & 1.7 & $h-k$ & 85.2 & ijk \\
\hline Oaxtepec & UACH-235 & 603 & h-p & Moderate & 37.5 & $\mathrm{c}-\mathrm{k}$ & 3.6 & bcd & 183 & $\mathrm{~b}$ \\
\hline Huamantla & UACH-236 & 735 & $\mathrm{f}-\mathrm{l}$ & Moderate & 33.5 & $f-n$ & 1.5 & $\mathrm{jk}$ & 89.5 & $\mathrm{~g}-\mathrm{k}$ \\
\hline Oaxtepec & UACH-237 & 748 & $\mathrm{f}-\mathrm{l}$ & Moderate & 27.9 & $i-n$ & 2.7 & $\mathrm{c}-\mathrm{k}$ & 159 & b-h \\
\hline Oaxtepec & UACH-238 & 745 & $\mathrm{f}-\mathrm{l}$ & Moderate & 57.1 & $\mathrm{ab}$ & 3.9 & $\mathrm{bc}$ & 173 & $\mathrm{bc}$ \\
\hline Oaxtepec & UACH-239 & 655 & $g-1$ & Moderate & 50.5 & bcd & 3.4 & b-e & 165.2 & b-e \\
\hline Huamantla & UACH-240 & 403 & op & Weak & 18.5 & $\mathrm{~m}-\mathrm{p}$ & 1.4 & $\mathrm{k}$ & 65 & jk \\
\hline Apanquetzalco & UACH-241 & 473 & $k-p$ & Moderate & 42.9 & $\mathrm{~b}-\mathrm{h}$ & 1.7 & h-k & 64 & $\mathrm{k}$ \\
\hline Control & & 30 & $\mathrm{q}$ & & 8.89 & $\mathrm{p}$ & 5.6 & $\mathrm{a}$ & 333 & $\mathrm{a}$ \\
\hline HSD & & 277 & & & 15.9 & & 1.4136 & & 73.362 & \\
\hline
\end{tabular}

Note: HSD: Honest significant difference. Different letters in each column indicates significant difference (Tukey, p <0.05).

and for global biodiversity assessments (Sites and Marshall, 2004) based on monophyletic grouping at higher levels and discover lineages at lower levels.

\section{Conclusions}

In conclusion, in the present study three Fusarium spp. (Fusarium oxysporum, Fusarium andiyazi, and Fusarium circinatum) associated with wilting disease of tomato in Mexico were identified, which will be very helpful information for developing new strategies for the adequate control of this pathogen. It was not find any relationship between the identified Fusarium species with the sampled areas and the production system; this shows the high capacity of this pathogen to affect tomato established under any condition due to the genetic variability of Fusarium, which affected the high variability of the infection period and growth rate as observed in this study. This situation can also explain the presence of the different species such as the Fusarium oxysporum complex, Fusarium andiyazi, and Fusarium circinatum in tomato; this is of significant important to continue monitoring and evaluating crop diseases development to avoid high losses in tomato production.

\section{Acknowledgements}

This work was supported by the National Council for Science and Technology of Mexico (CONACYT). Micah Royan Isaac holds a scholarship (439506) for his doctorate studies in Horticulture. We are also thankful to the Tomato Breeding Program (Project No. 17001-C) and the Laboratory of Mycology of the Department of Agricultural Parasitology through the Investigation project (E-146788) of the Universidad Autónoma Chapingo, Mexico for their support during this investigation. 
492

\section{References}

Ajit NS, Verma R, Shanmugam V (2006). Extracellular chitinases of fluorescent Pseudomonads antifungal to $F$. oxysporum f.sp. dianthi causing carnation wilt. Current Microbiology 52:310-316.

Akanmu AO, Abiala MA, Odebode AC (2013). Pathogenic effect of soilborne Fusarium species on the growth of millet seedlings. World Journal of Agricultural Sciences 9:60-68.

Aoki T, O'Donnell K, Geiser DM (2014). Systematics of key phytopathogenic Fusarium species: Current status and future challenges. Journal of General Plant Pathology 80:189-201.

Apodaca SMA, Zavaleta ME, Osada KS, García ER, Valenzuela UJG (2004). Hospedantes asintomáticos de Fusarium oxysporum Schlechtend. f. sp. radicis-lycopersici W.R Jarvis y Shoemaker en Sinaloa, México. Revista Mexicana de Fitopatología 22:7-13.

Arie T, Takahashi H, Kodama M, Teraoka T (2007). Tomato as a model plant for plant-pathogen interactions. Plant Biotechnology 24:135-147.

Bashyal BM, Aggarwal R (2013). Molecular identification of Fusarium species associated with bakanae disease of rice (Oryza sativa) in India. Indian Journal of Agricultural Sciences 83:71-76.

Booth C (1971). The genus Fusarium. Commonwealth Mycological Institute, Kew, Surrey, England.

Britz H, Coutinho TA, Wingeld MJ, Marasas WFO (2002). Validation of the description of Gibberella circinata and morphological differentiation of the anamorph Fusarium circinatum. Sydowia 54:9-22.

Cai L, Giraud T, Zhang N, Begerow D, Cai G, Shivas GR (2011). The evolution of species concepts and species recognition criteria in plant pathogenic fungi. Fungal Diversity 50:121.

Campbell CL, Madden LV (1990). Introduction to plant disease epidemiology.John Wiley and Sons, Inc, New York, NY, USA.

Chehri K, Salleh B, Zakaria L (2015). Morphological and phylogenetic analysis of Fusarium solani species complex in Malaysia. Microbial Ecology 69:457-471.

Correia CK, Câmara SM, Barbosa GM, Sales RJ, Brisach AC, Gramaje D, ... Michereff SJ (2013). Fungal trunk pathogens associated with table grape decline in Northeastern Brazil. Phytopathologia Mediterranea 53:380-388.

Daami-Remadi M (2006). Etude des fusarioses de la pomme de terre [Study of fusariosis of the potato]. Thèse, Institut Supérieur 424 Agronomique deChott-Mariem, Tunisie.

El-Kazzaz MK, El-Fadly GB, Hassan MAA, El-Kot GAN (2008). Identification of some Fusarium spp. using Molecular Biology Techniques, Egypt Journal of Phytopathology 36:57-69.

FAOSTAT (2015). Database on Agriculture. FAO - Food and Agriculture Organization of the United Nations.

Gargouri-Kammoun L, Gargouri S, Rezgui S, Trifi M, Bahri N, Hajlaoui M R (2009). Pathogenicity and Aggressiveness of Fusarium and Microdochium on Wheat Seedlings under Controlled Conditions. Tunisian Journal of Plant Protection 2:135-144.

Giurgiu MR, Dumitraș A, Morar G, Scheewe P, Schröder GF (2017). A study on the biological control of Fusarium oxysporum using Trichoderma spp., on soil and rockwool substrates in controlled environment. Notulae Botanicae Horti Agrobotanici Cluj-Napoca 46(1):260-269.
Hernández-MartínezHR, BenítezLA, Escalante BF, VelázquezEJ, Aspeytia SD, Mendoza MIE, Ochoa LAL (2014). Razas de Fusarium oxysporum f. sp. lycopersici en predios tomateros en San Luis Potosí. Revista Mexicana de Ciencias Agrícolas 5:1169-1178.

Hsuan HM, Salleh B, Zakaria L (2011). Molecular identification of Fusarium species in Gibberella fujikuroi species complex from rice, sugarcane and maize from Peninsular Malaysia. International Journal of Molecular Sciences 12:6722-6732.

Inami K, Kashiwa T, Kawabe M, Onokubo-Okabe A, Ishikawa N, Pérez $\mathrm{RE}, .$. Arie $\mathrm{T}$ (2014). The tomato wilt fungus Fusarium oxysporum $\mathrm{f}$.sp. lycopersici shares common ancestors with nonpathogenic $F$. oxysporum isolated from wild tomatoes in the Peruvian Andes. Microbes and Environments 29:200-210.

Irzykowska L, Bocianowski J, Waśkiewicz A, Weber Z, Karolewski Z, Goliński P, Kostecki M, Irzykowski W (2012). Genetic variation of Fusarium oxysporum isolates forming fumonisin $\mathrm{B} 1$ and moniliformin. Journal of Applied Genetics 53:237-247.

Jiménez-Fernández D, Montes-Borregob M, Navas Cortés J, Jiménez-D'iaz R, Landab, BB (2010). Identification and quantification of Fusarium oxysporum in plants and soil by means of an improved specific and quantitative PCR assay. Applied Soil Ecology 46:372-362.

Joshi, M, Srivastava R, Sharma Prakash AK (2013). Isolation and characterization of Fusarium oxysporum, a wilt causing fungus, for its pathogenic and non-pathogenic nature in tomato (Solanum lycopersicum). Journal of Applied and Natural Science 5:108-117.

Klaasen JA, Nelson PE (1996). Identification of a mating population, Gibberella nygamai sp. nov., within the Fusarium nygamai anamorph. Mycologia 88:965-969.

Klittich CJR, Leslie JF, Nelson PE, Marasas WFO (1997). Fusarium thapsinum (Gibberella thapsina): a new species in section Liseola from sorghum. Mycologia 89:643-652.

Lamrani K (2009). Etude de la biodiversité des moisissures nuisibles et utiles isolées à partir des Maâsra du Maroc [Study of the biodiversity of harmful and beneficial fungi isolated from the Maasra of Morocco]. Thése en Microbiologie, Université Mohamed V-Agdal Faculté des Sciences Rabat. N'd'ordre: 2461.

Leslie JF, Summerell BA (2006). The Fusarium Laboratory Manual. Blackwell Publishing, Iowa, USA.

Leyva-Mir, SG, González-Solano CM, Rodríguez-Pérez JE, and MontalvoHernández D (2013). Behavior of advanced lines of tomato (Solanum lycopersicum L.) to phytopathogens at Chapingo, Mexico. Revista ChapingoSerie Horticultura 19:301-313.

Lima CS, Pfenning LH, Costa SS, Abreu LM, Leslie JF (2012). Fusarium tupiense sp. nov., a member of the Gibberella fujikuroi complex that causes mango malformation in Brazil. Mycologia 104:1408-1419.

Marzano M, Gallo A, Altomare C (2013). Improvement of biocontrol efficacy of Trichoderma harzianum vs. Fusarium oxysporum f. sp. lycopersici through UV-induced tolerance to fusaric acid. Biological Control 67:397-408.

Marín-Montes IM, Rodríguez-PérezJE, Sahagún-Castellanos J, HernandezIbañez L, Velasco-García AM (2016). Variación morfológica y molecular de 55 colectas de tomate nativo de México. Revista Chapingo Serie Horticultura 22:117-132. 
Massee G (1895). The "Sleepy disease" of tomatoes. Garden Chronicles Series 3 17:707-708.

Marasas WFO, Lamprecht SC, Zeller KA, Leslie JF (2001). Fusarium andiyazi sp. nov., a new species from sorghum. Mycologia 93:12031210.

Morales-Rodríguez I, Yañez-Morales M, Silva-Rojas HV, García de los Santos G, Guzmán de Peña D (2007). Biodiversity of Fusarium species in Mexico associated with ear rot in maize, and their identification using a phylogenetic approach. Mycopathologia 163:31-39.

Nelson PE, Toussoun TA, Marasas WFO (1983). Fusarium Species: An Illustrated Manual for Identification. Pennsylvania State University Press, University Park, Pennsylvania, USA.

Nirenberg HI, O'Donnell K (1998) New Fusarium species and combinations within the Gibberella fujikuroi species complex. Mycologia 90:434458.

Nirmaladevi D, Venkataramana M, Srivastava RK, Uppalapati SR, Gupta VK, Yli-Mattila T, ... Chandra NS (2016). Molecular phylogeny, pathogenicity and toxigenicity of Fusarium oxysporum f. sp. bycopersici. Scientific Reports 6:21367.

O’Donnell K, Cigelnik E, Casper HH (1998). Molecular phylogenetic, morphological, and mycotoxin data support re-identification of the Quorn mycoprotein fungus as Fusarium venenatum. Fungal Genetics and Biology 23:57-67.

O'Donnell K, Cigelnik E, Nirenberg HI (1998). Molecular systematics and phylogeography of the Gibberella fujikuroi species. Mycologia 90:465493.

Panthee DR, Chen F (2010). Genomics of fungal disease resistance in tomato. Current Genomics 11:30-39.

Parke JL, Grünwald NJ (2012). A systems approach for management of pests and pathogens of nursery crops. Plant Diseases 96:1236-1244.

Rodrigues AAC, Menezes M (2005). Identification and pathogenic characterization of endophytic Fusarium species from cowpea seeds. Mycopathologia 159:79-85.

SAS Institute Inc (2012). Base SAS 9.3 Procedures Guide. Cary, NC: SAS Institute Inc.

Sato R, Araki T (1974). On the tomato root-rot disease occurring under vinyl-house conditions in southern Hokkaido. Annual Report of the Society of Plant Protection of North Japan 25:5-13.

Shahnazi S, Meon S, Vadamalai G, Ahmad K, Nejat N (2012). Morphological and molecular characterization of Fusarium spp. associated with yellowing disease of black pepper (Piper nigrum L.) in Malaysia.Journal of General Plant Pathology 78:160-169.

Siddique SS, Bhuiyan MKA, Momotaz R, Bari GMM, Rahman MH (2014). Cultural characteristics, virulence and In-vitro chemical control of Fusarium oxysporum $\mathrm{f}$. sp.phaseoli of bush bean (Phaseolus vulgaris L.), The Agriculturists 12:103-110.

Singha MI, Kakoty Y, Unni GB, Das J, Kalita CM (2016). Identification and characterization of Fusarium sp. using ITS and RAPD causing Fusarium wilt of tomato isolated from Assam, North East India. Journal ofGenetic Engineering and Biotechnology 14:99-105.

Sites JW, Marshall JC (2004). Operational criteria for delimiting species. Annual Review of Ecology Evolution and Systematics 35:199-227.

Staden R, Beal KF, Bonfield JK (1998). The Staden package, 1998. In: Misener S, Krawetz SA (Eds). Bioinformatics methods and protocols.
Humana, New York pp 115-130.

Steenkamp ET, Wingfield BD, Desjardins AE, Marasas WFO, Wingfield MJ (2002). Cryptic Speciation in Fusarium subglutinans. Mycologia 94:1032-1043.

Steenkamp ET, Makhari OM, Coutinho TA, Wingfield BD, Wingfield MJ (2014). Evidence for a new introduction of the pitch canker fungus Fusarium circinatum in South Africa. Plant Pathology 63(3):530-538.

Steinkellner S, Mammerler R, Vierheilig H (2005). Microconidia germination of the tomato pathogen Fusarium oxysporum in the presence of root exudates. Journal of Plant Interactions 1:23-30.

Sweet CL, Gordon TR (2012). First report of grass species (Poaceae) as naturally occurring host of the pine pathogen Gibberella circinata. Plant Disease 96(6):908.

Takken F, Rep M (2010). The arms race between tomato and Fusarium oxysporum. Molecular Plant Pathology 11:309-314.

Tamura K, Peterson D, Peterson N, Stecher G, Nei M, Kumar S (2011). MEGA5: Molecular Evolutionary Genetics Analysis using maximum likelihood, evolutionary distance, and maximum parsimony methods. Molecular Biology and Evolution 28:2731-2739.

Tamura K, Nei M (1993). Estimation of the number of nucleotide substitutions in the control region of mitochondrial DNA in humans and chimpanzees. Molecular Biology and Evolution 10:512-526.

Tanyolac B, Akkale C (2010). Screening of resistance genes to Fusarium root rot and Fusarium wilt diseases in $\mathrm{F} 3$ family lines of tomato (Lycopersicon esculentum) using RAPD and CAPs. African Journal of Biotechnology 9:2727-2730.

Thompson JD, Gibson TJ, Plewniak F, Jeanmougin F, Higgins DG (1997). The ClustalX Windows interface: flexible strategies for multiple alignment aided by quality analysis tools. Nucleic Acids Research 25:4876-4882.

Tivoli B, Deltour A, Molet D, Bedin P, Jouan B (1986). Mise en évidence de souches de Fusarium roseum var. sambucinum résistantes au thiabendazole, isolées à partir de tubercules de pomme de terre [Demonstration of Fusarium roseum var. sambucinum strains resistant to thiabendazole, isolated from potato tubers]. Agronomie 6:219-224.

Trabelsi R, Sellami H, Gharbi Y, Krid S, Cheffi M, Kammoun S, ... Triki MA (2017). Morphological and molecular characterization of Fusarium spp. associated with olive trees dieback in Tunisia. Biotechnology 7:1.

Van Hove F, Waalwijk C, Logrieco A, Munaut F, Moretti A (2011). Gibberella musae (Fusarium musae) sp. nov., a recently discovered species from banana is sister to F. verticillioides. Mycologia 103:570-585.

White TJ, Bruns T, Lee S, Taylor J (1990). Amplification and direct sequencing of fungal ribosomal RNA genes for phylogenetics. In: PCR protocols: A guide to methods and applications. Innis MA, Gelfand DH, Sninsky JJ, White TJ (Eds). Academic Press, New York, USA 315-322.

WulffEG, Sorensen JL, Lubeck M, Nielson KF, Thrane U, Trop J (2010). Fusarium spp. associated with rice Bakanae: ecology, genetic diversity, pathogenicity and toxigenicity. Environmental Microbiology 12(3):649-657.

Zainuddin M, Ain Izzati N, Baharuddin S (2010). Variability of Fusarium species associated with bakanae disease of rice based on virulence, vegetative and biological compatibility. Sydowia 62:89-104. 